\title{
Exergy analysis and performance evaluation of Kizildere Geothermal Power Plant, Turkey
}

\author{
Eda Didem Yildirim and Gulden Gokcen* \\ Mechanical Engineering Department, Faculty of Engineering, \\ Izmir Institute of Technology, 35437 Gulbahce Koyu, Urla, \\ Izmir, Turkey \\ Fax: +90-232-7506505 E-mail: edayildirim@iyte.edu.tr \\ E-mail: guldengokcen@iyte.edu.tr \\ *Corresponding author
}

\begin{abstract}
Conventional geothermal power plants (GPP) differ from fossil-fuel power plants (FFPP) in many ways. The most specific ones are GPPs, are not cyclic plants and the working fluid is not pure steam. Geothermal steam contains non-condensable gases (NCG) which degrade power plant efficiency. This discrepancy leads to two considerations in energy and exergy analysis of GPPs. One is that the amount of NCGs in the steam cannot be omitted during the calculations; the other is that the dead state composition varies throughout the process. In this work, energy and exergy analysis is conducted to assess the performance of Kizildere GPP under both considerations.
\end{abstract}

The net second law efficiencies of the plant based on reservoir and wellhead exergy are 24.3 and $27.2 \%$ respectively. Both indicate that the plant performance is low comparing with the other single-flash GPPs and FFPPs.

The losses are mainly associated with high NCG content and low steam fraction of the fluid.

Keywords: exergy analysis; geothermal power plants; non-condensable gases; Turkey; variable dead state.

Reference to this paper should be made as follows: Yildirim, E.D. and Gokcen, G. (2004) 'Exergy analysis and performance evaluation of Kizildere Geothermal Power Plant, Turkey', Int. J. Exergy, Vol. 1, No. 3, pp.316-333.

Biographical notes: Eda Didem Yildirim was awarded a BSc from the Mechanical Engineering Department of Ege University Izmir-Turkey. She has been studying her MSc since 2002 and is currently working as a Research Assistant at the Mechanical Engineering Department of Izmir Institute of Technology.

Gulden Gokcen received her BSc from the Mechanical Engineering Department of Dokuz Eylul University, Izmir-Turkey, and her MSc and $\mathrm{PhD}$ from the Solar Energy Institute of Ege University, Izmir-Turkey. She joined a one year 'Geothermal Technology Diploma Course' in 1996 at the Geothermal Institute of Auckland University, New Zealand and received a NATO A2 Research Fund fellowship and worked on her $\mathrm{PhD}$ thesis in Denver, Colorado, USA in 1997. She worked as a Research Assistant from 1991-2000 at Ege University. After receiving her PhD in 2000, she started 
work at the Mechanical Engineering Department of Izmir Institute of Technology as Assistant Professor. She has been lecturing and conducting research on geothermal energy technologies, thermodynamics and heat exchangers.

\section{Introduction}

Turkey has dynamic economic development and rapid population growth, therefore, meeting the energy demand is of great importance. Using the country's large energy efficiency potential is the best way to meet the demand. In this regard, renewable energy sources appear to be one of the most efficient and effective solutions for sustainable energy development. Turkey's geographical location has several advantages for extensive use of most of the renewable energy sources, such as geothermal, wind, solar energy and biomass.

The studies on renewable energy sources in Turkey were initiated in the 1960s but did not exhibit significant progress at that time except with hydropower, as was the case in several developed countries.

Today in Turkey, biomass and hydropower are mostly in use, with geothermal power in third place. Renewable energy sources account for $30 \%$ of the total energy consumption of the country and $0.23 \%$ of which accounts for geothermal (WEC-TNC, 2000).

In Turkey, around 600 geothermal prospects and 170 geothermal fields with a temperature range of $40-242^{\circ} \mathrm{C}$ have been discovered. The estimated geothermal power and direct use potential are reported as $4500 \mathrm{MW}_{\mathrm{e}}$ and $31500 \mathrm{MW}_{\mathrm{t}}$, respectively. The total proven geothermal electricity generation capacity is $200 \mathrm{MW}_{\mathrm{e}}$ while direct use capacity is $2046 \mathrm{MW}_{\mathrm{t}}$. This proven potential increases by $5 \%$ annually with new exploration and drilling activities. The potential of geothermal development in Turkey is generally considered large in terms of moderate and low temperature resources $\left(<150^{\circ} \mathrm{C}\right)$. Therefore, the resources are mostly suitable for direct use applications (TGA, 2003).

Utilisation of geothermal energy for electricity generation is advantageous because of its relatively low installation and operational cost, as well as being more environmentally friendly in comparison to conventional thermal and hydraulic power plants. Geothermal electricity generation plays a minor role in Turkey's electricity capacity as $0.07 \%$ but the projections foresee an improvement to $0.32 \%$ by the year 2020.

High temperature geothermal fields suitable for conventional electricity generation are Denizli-Kizildere $\left(200-242^{\circ} \mathrm{C}\right)$, Aydin-Germencik $\left(232^{\circ} \mathrm{C}\right)$, Aydin-Salavatli $\left(171^{\circ} \mathrm{C}\right)$, Canakkale-Tuzla $\left(173^{\circ} \mathrm{C}\right)$, Kutahya-Simav $\left(162^{\circ} \mathrm{C}\right)$ and Izmir-Seferihisar $\left(150^{\circ} \mathrm{C}\right)$. The only operating geothermal power plant of Turkey is Kizildere Geothermal Power Plant (GPP), which is located near Denizli City in Western Anatolia. Kizildere GPP was installed in 1984 with a capacity of $20.4 \mathrm{MW}_{\mathrm{e}}$. Average electric power produced by the plant was encountered as $10.45 \mathrm{MW}_{\mathrm{e}}$ which accounts for only $51 \%$ of its installed capacity, between 1998 and 2001 (EGIC, 2002). The total capacity of the field is estimated to be $200 \mathrm{MW}_{\mathrm{e}}$. 
The energy analysis tools used to improve the heat transfer equipment in industry are still based on the first law of thermodynamics and it is becoming more and more difficult to identify inefficiencies and their limits for further improvement (Bilgen and Takahashi, 2002). It is possible to design more efficient energy systems by reducing the inefficiencies in existing systems. But first of all the irreversibilities in each component of the system should be analysed by using 'Exergy Analysis'. Exergy analysis is a powerful tool for assessing the thermodynamic efficiencies and losses of the system and processes (Struchtrup and Rosen, 2002). It requires a combination of the first and second law of thermodynamics and shows the relationship between the exergetic efficiency of an individual element and that of the whole system (Nikulshin et al., 2002).

Exergy analysis answers the questions of where, why and how much available work is lost in the system. The present study describes the details of energy and exergy based performance characteristics of Kizildere GPP. By using the calculated data of exergy destruction of each element, the states of exergy loss and reasons for the low electric power production rate can be determined. After evaluating the second-law efficiency of the system, possible improvements can be suggested.

\section{Overview of Kizildere Geothermal Power Plant}

The Kizildere Geothermal Field (GF) is a liquid dominated system with a reservoir temperature of $200-242^{\circ} \mathrm{C}$ and a steam fraction of $10-20 \%$. The most significant characteristic of the field is a considerable amount of non-condensable gases (NCGs), which is $2.5 \%$ in the reservoir, $10-21 \%$ at the wellhead and average $16 \%$ by weight of steam at the turbine inlet. The major component of NCGs is carbon dioxide $\left(\mathrm{CO}_{2}\right)$, which causes the greenhouse effect globally. $\mathrm{CO}_{2}$ is extracted from the condenser and sent to a $\mathrm{CO}_{2}$ plant to produce liquid $\mathrm{CO}_{2}$ and dry ice with a capacity of 80,000 tons/a. $\mathrm{H}_{2} \mathrm{~S}$ content in the field is under the exposure limits.

A flow diagram of Kizildere GPP is given in Figure 1. Kizildere GPP is a single flash design with a direct contact condenser. Twenty-two production wells have been drilled, only nine of which (KD 6, KD 13, KD 14, KD 15, KD 16, KD 20, KD $21, \mathrm{KD} 22, \mathrm{R} 1)$ are being operated. The average steam flow rate to the turbine is $33.3 \mathrm{~kg} / \mathrm{s}$.

The geothermal fluid extracted is saturated vapour-liquid- $\mathrm{CO}_{2}$ mixture. When the geothermal fluid reaches the wellhead, it is directed to a separator where steam and liquid phases are separated. Steam is then sent to the turbine where the electrical power is maintained while $257.7 \mathrm{~kg} / \mathrm{s}$ liquid, which is $88.5 \%$ of the total flow rate, is rejected to the Buyuk Menderes River through a $1.8-\mathrm{km}$ long channel. A small fraction of the liquid has been injected back to the reservoir since 2002 by Well R2. The turbine exit is connected to a direct-contact condenser. The steam and NCGs enter the condenser with a pressure of $0.01 \mathrm{MPa}$, NCGs are extracted by a three-stage compressor unit with inter-cooling and sent to the $\mathrm{CO}_{2}$ plant. A mechanical draft-cooling tower is used to maintain the cooling water for the condenser (Gokcen et al., 2004). 
Figure 1 Flow diagram of Kizildere Geothermal Power Plant

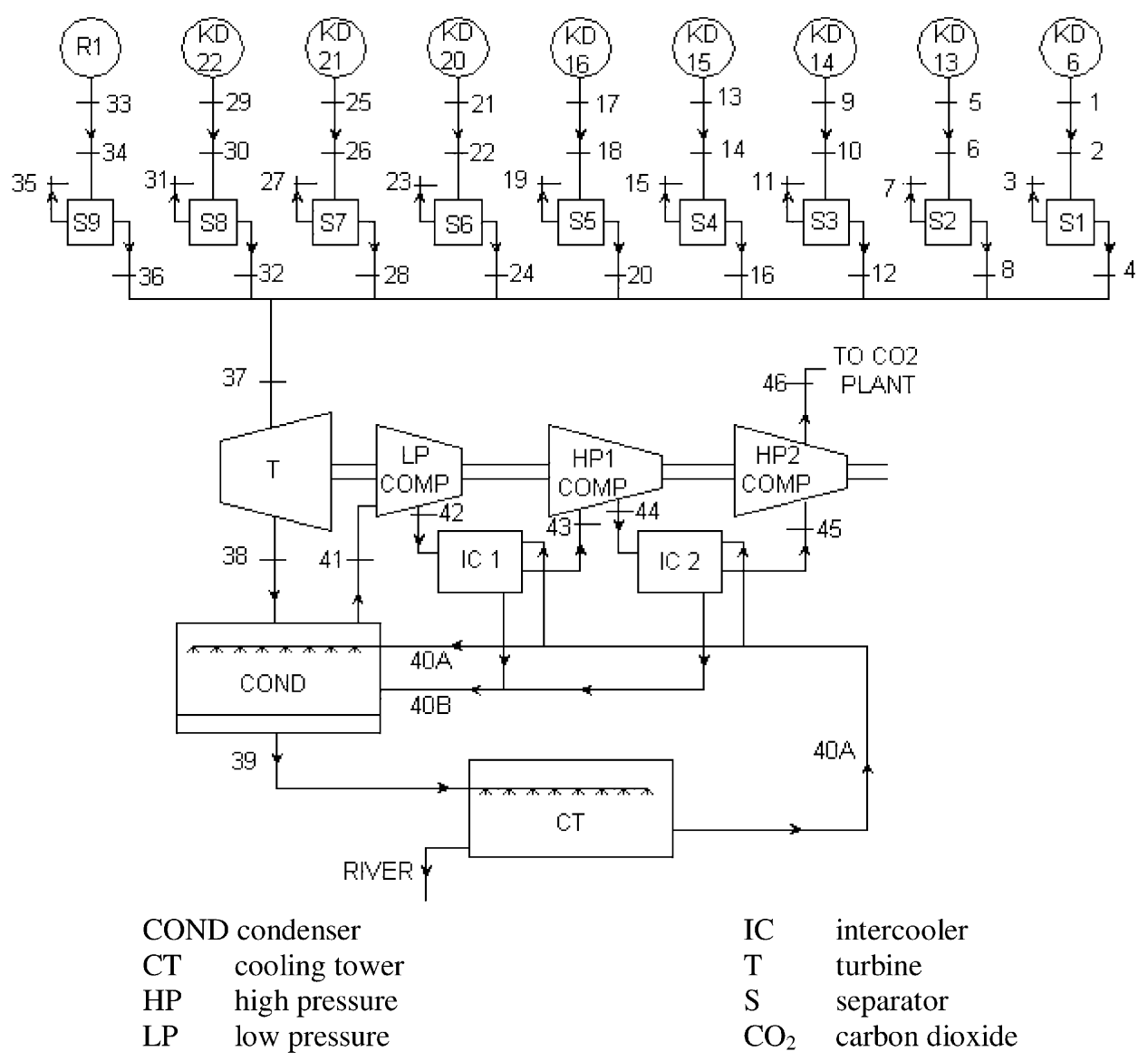

\section{Influence of noncondensable gases}

NCGs are found widely in geothermal fluids $\left(\mathrm{CO}_{2}, \mathrm{H}_{2} \mathrm{~S}, \mathrm{CH}_{4}, \mathrm{~N}_{2}, \mathrm{He}, \mathrm{H}_{2}\right.$, etc. $)$ are natural components of geothermal fluids, and they are a source of considerable capital and operating costs for power plants. The gas content of geothermal steam varies considerably across the world from almost zero to as much as $25 \%$ by weight of steam. Table 1 gives the NCG content of various geothermal fields. Kizildere GF is one of the highest NCG content-fields in the World. The major component of NCGs is $\mathrm{CO}_{2}$ which typically constitutes over $90 \%$ of the gases. According to Michaelides (1982), the mixture of the NCG will be replaced with a $\mathrm{CO}_{2}$ equivalent mass fraction, when $\mathrm{CO}_{2}$ constitutes more than $80 \%$ in total $\mathrm{NCG}$. 
Table 1 NCG content of geothermal fields (Hall, 1996)

\begin{tabular}{ll}
\hline Geothermal field & Non-condensable gas content (\% by weight of steam) \\
\hline The Geysers-USA & 0.5 (early development) \\
& 2.0 (later development) \\
Puna-Hawaii & 0.1 \\
Wairakei-New Zealand & 0.2 \\
Salak-Indonesia & 0.34 \\
Ohaaki-NZ & 3.0 \\
BacMan-The Philippines & 5 \\
Larderello-Italy & 10 \\
Kizildere-Turkey & $10-21$ \\
\hline
\end{tabular}

NCGs are usually withdrawn from the condenser by vacuum equipment. All methods of removing the gases consume energy in the form of steam or electrical power that would otherwise increase the net saleable power plant product. Energy consumption to remove NCGs increases with increasing NCG content. This applies to all steam-driven power plants, including fossil-fuel systems, but it is especially costly in geothermal systems because of elevated gas levels (Vorum and Fritzler, 2000).

NCGs also decrease the exergy of the fluid, thus reducing the available work in the plant. The power delivered by the turbine is affected by the presence of NCGs. Thus, evaluation of the net work of the turbine should consider the presence of NCGs. The energy recovered in the turbine when the NCGs are present, is lower than the energy recovered when the NCG are not present, because the NCG displace volume of the steam (Montero, 1990). Therefore, NCGs should not be omitted in exergy analysis.

\section{Exergy analysis of the plant}

The maximum possible work as a system undergoes a reversible process from the specified initial state to a defined state is called 'Exergy' or 'Availability'.

Geothermal fluid at the wellhead has a capacity to do work. It can be taken through a series of processes to extract as much as energy from that fluid. Heat is exchanged between the fluid and surroundings and is finally discharged to the surroundings in a state influenced by the ambient conditions.

Exergy is calculated as

$$
\dot{\mathrm{E}}=\dot{\mathrm{m}}\left[\left(\mathrm{h}-\mathrm{h}_{0}\right)-\mathrm{T}_{0}\left(\mathrm{~s}-\mathrm{s}_{0}\right)\right] .
$$

The calculation of the exergy requires the definition of a dead state (Khalifa and Michaelides, 1978). The dead state is considered variable due to the non-cyclic behaviour of GPPs and the variable fluid composition throughout the process. The dead state is defined specific to the composition of each state at the ambient pressure $\left(\mathrm{P}_{\mathrm{o}}\right), 0.101 \mathrm{MPa}(\sim 1 \mathrm{~atm})$, and the ambient temperature $\left(\mathrm{T}_{\mathrm{o}}\right), 18^{\circ} \mathrm{C}$. 
The actual power (W) developed by a system can be compared with the maximum possible power (exergy) and a second-law efficiency can be expressed as

$$
\eta_{I I}=\frac{\mathrm{W}}{\mathrm{E}_{\mathrm{in}}} .
$$

The exergy analysis is more suitable than the energy analysis to assess the performance of GPPs since geothermal energy sources have a relatively low temperature and processes are not cyclic (Setiawan, 1996).

In the second law analysis of geothermal power plants, exergy of geothermal fluid is computed at all states and changes in exergy are determined for each major component. Unlike energy, exergy is not conserved but destroyed in the system. In separators of the plant, exergy destruction occurs due to the unused liquid phase at the separator exit. Different from the separation part, in the other sections of the plant exergy is dissipated during a process because of friction, mixing, heat transfer, etc. The source of exergy losses in both the turbine and compressor is mainly frictional, thermal losses in the flow path (Song et al., 2002) and NCGs, in the generator is the result of the mechanical destruction (friction and the electrical dissipations), in the heat exchangers of the system (condenser, cooling tower, intercoolers) is due to the large temperature difference between the hot and cold fluid and NCGs. The larger the temperature difference, the larger the exergy losses and the less the efficiency (Nikulshin et al., 2002).

Exergy destruction and exergetic efficiency in the turbine and compressors can be evaluated as follows:

Turbine

$$
\begin{gathered}
\dot{E}_{L, t u r b}=\dot{E}_{\text {in }, \text { turb }}-\dot{E}_{\text {out }, \text { turb }}-\dot{W}_{\text {turb }} \\
\varepsilon_{\text {turb }}=\frac{\dot{W}_{\text {turb }}}{\dot{E}_{\text {in }, \text { turb }}-\dot{E}_{\text {out }, \text { turb }}}
\end{gathered}
$$

Compressor

$$
\begin{gathered}
\dot{E}_{L, \text { comp }}=\dot{E}_{\text {in }, \text { comp }}-\dot{E}_{\text {out }, \text { comp }}+\dot{W}_{\text {comp }} \\
\varepsilon_{\text {comp }}=\frac{\dot{E}_{\text {out }, \text { comp } p}-\dot{E}_{\text {in, comp }}}{\dot{W}_{\text {comp }}}
\end{gathered}
$$

Cooling tower and condenser

$$
\begin{gathered}
\dot{E}_{L}=\dot{E}_{\text {in }}-\dot{E}_{\text {out }} \\
\varepsilon_{\text {comp }}=\frac{\dot{E}_{\text {out }}}{\dot{E}_{\text {in }}} .
\end{gathered}
$$


Exergy destruction of any plant component be expressed as

$$
\dot{E}_{L}=\dot{E}_{\text {in }}-\dot{E}_{\text {out }} .
$$

The steam phase of the geothermal fluid is generally considered as pure steam in energy and exergy calculations. If the NCG content is low, this would give an acceptable error but for the geothermal fluids which contain a considerable amount of NCGs this assumption will not be reliable. The steam phase should therefore be considered as steam and $\mathrm{CO}_{2}$ mixture at a given temperature and pressure. The specific enthalpy and entropy of the mixture is given by

$$
\begin{aligned}
& \mathrm{h}_{\text {mix }}=\mathrm{fh}_{\mathrm{CO}_{2}, \mathrm{~T}}+[1-\mathrm{f}] \mathrm{h}_{\mathrm{s}, \mathrm{T}} \\
& \mathrm{s}_{\text {mix }}=\mathrm{fs}_{\mathrm{CO}_{2}, \mathrm{~T}}+[1-\mathrm{f}] \mathrm{s}_{\mathrm{s}, \mathrm{T}} .
\end{aligned}
$$

Exergy analysis is performed for both steam field and power plant. A steam field consists of wells, separators, silencers and a waste-water channel while a power plant constitutes turbine-generator group, compressor unit, intercoolers, condenser and a cooling tower.

Using the temperature, pressure and flow rate data of each specified state in Figure 1, energy and exergy rate is calculated and given in Table 2 for steam field and in Table 3 for power plant.

Some reference conditions taken and some assumptions are made as follows:

- Geothermal fluid is a saturated vapour-liquid mixture at the wellhead.

- The properties of saturated liquid are determined under the assumption of incompressible fluid with constant specific heat.

- The NCG content is considered at each state of the flow diagram to ensure the calculations reflect the site condition since the NCG content is high in the field. The presence of NCGs is treated as only $\mathrm{CO}_{2}$ since it constitutes $96-99 \%$ of the NCGs.

- $\mathrm{CO}_{2}$ behaves as an ideal gas in each step.

- The state of the turbine inlet condition is defined as vapour and $\mathrm{CO}_{2}$ mixture. The average $\mathrm{CO}_{2}$ fraction in the turbine inlet steam is taken as $16 \%$ by wt.

- The water vapour fraction in the low pressure (LP) compressor is $14 \%$ which cannot be neglected.

- Turbine and compressor efficiencies are assumed to be $75 \%$ and generator efficiency is assumed to be $90 \%$.

- Condensation rate in the condenser and intercoolers are assumed to be $96 \%$.

- The properties of the dead state varies depending on the composition of each state at the ambient pressure $\left(\mathrm{P}_{\mathrm{o}}\right), 0.101 \mathrm{MPa}(\sim 1 \mathrm{~atm})$, and the ambient temperature $\left(\mathrm{T}_{\mathrm{o}}\right), 18^{\circ} \mathrm{C}$. 
Table 2 Steam field properties

\begin{tabular}{|c|c|}
\hline 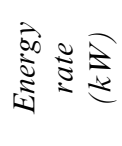 & 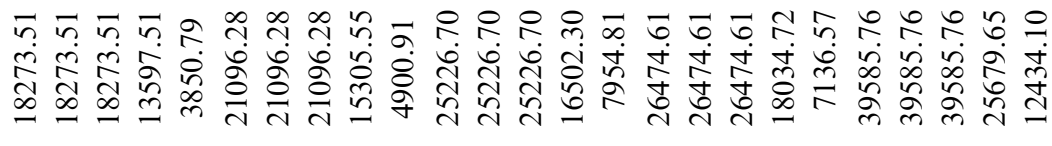 \\
\hline 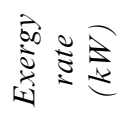 & 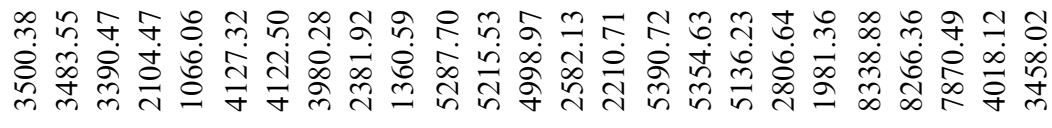 \\
\hline 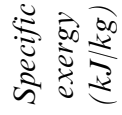 & 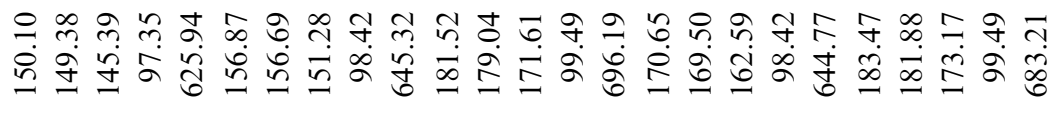 \\
\hline 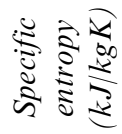 & 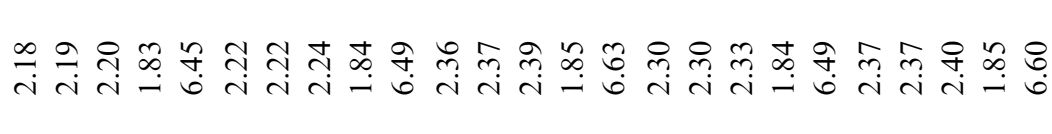 \\
\hline 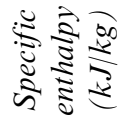 & 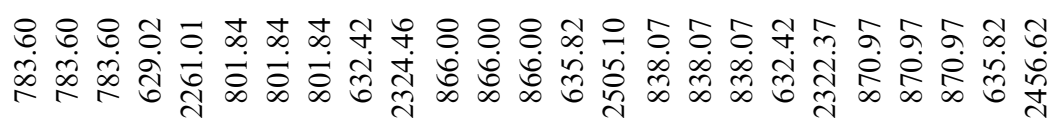 \\
\hline 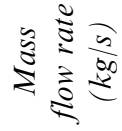 & 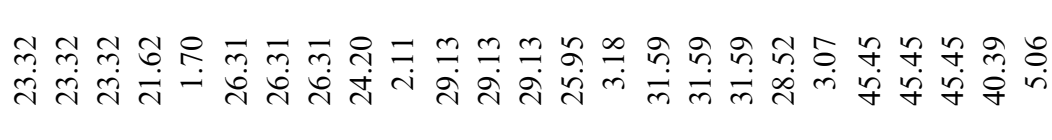 \\
\hline 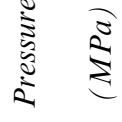 & 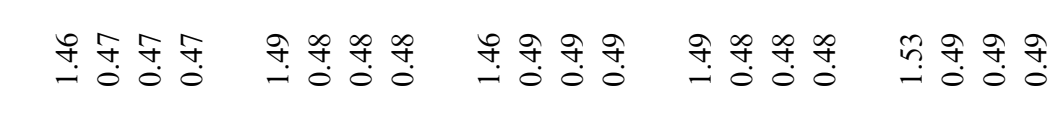 \\
\hline 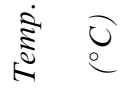 & 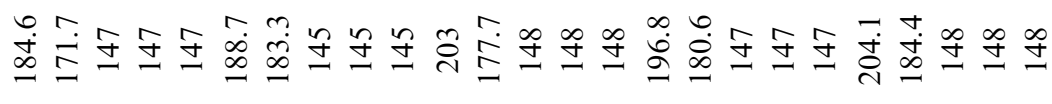 \\
\hline 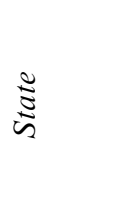 & 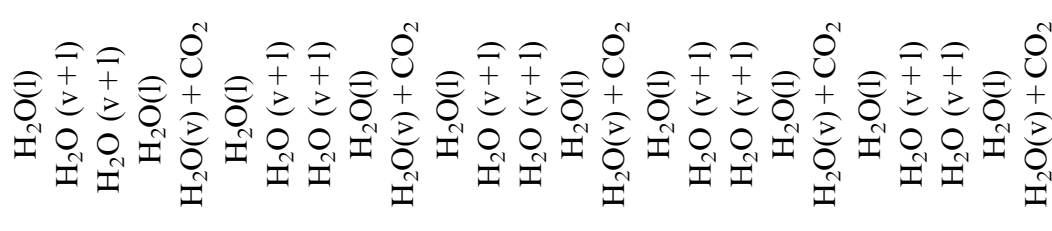 \\
\hline 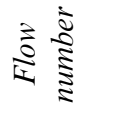 & 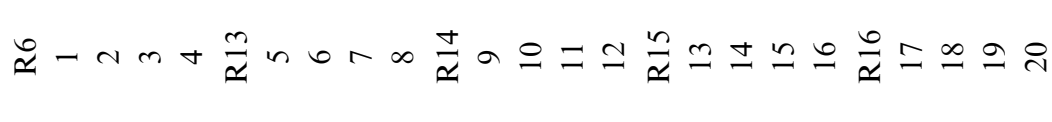 \\
\hline & $\frac{m}{2}$ \\
\hline 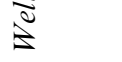 & 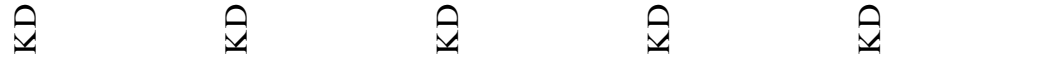 \\
\hline
\end{tabular}


Table 2 Steam field properties (continued)

\begin{tabular}{|c|c|c|c|c|}
\hline 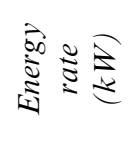 & 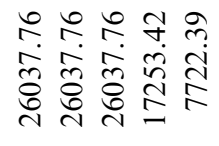 & 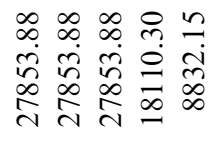 & 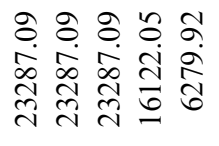 & 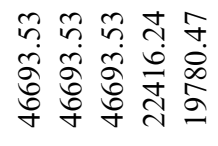 \\
\hline 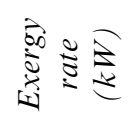 & 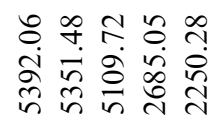 & 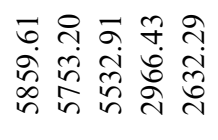 & 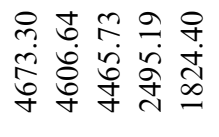 & 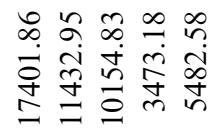 \\
\hline 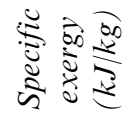 & 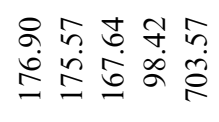 & 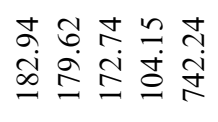 & 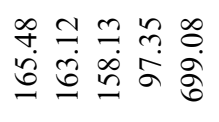 & 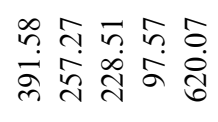 \\
\hline 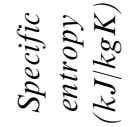 & 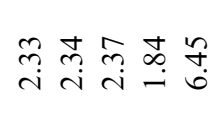 & 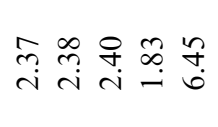 & તָ & 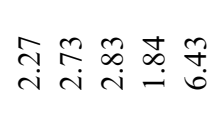 \\
\hline 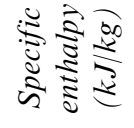 & 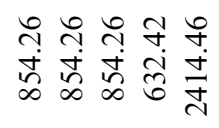 & 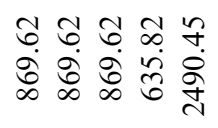 & 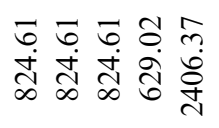 & 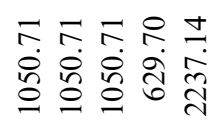 \\
\hline 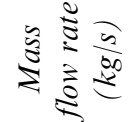 & 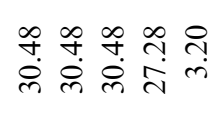 & 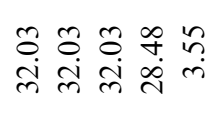 & 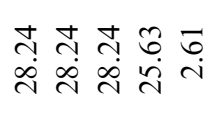 & 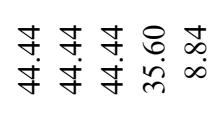 \\
\hline $\begin{array}{l}\vdots \\
\vdots \\
\vdots \\
\vdots \\
\vdots\end{array}$ & 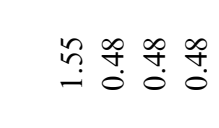 & 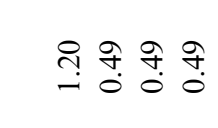 & 守守守守 & 䓇守守 \\
\hline 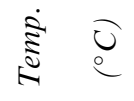 & 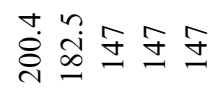 & 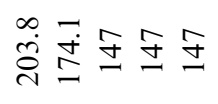 & 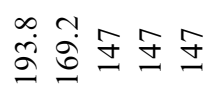 & 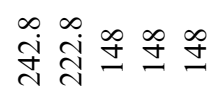 \\
\hline$\underset{5}{\overline{5}}$ & 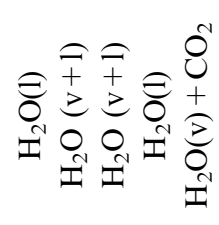 & 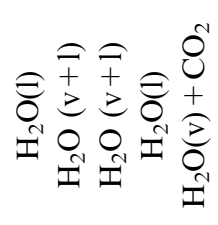 & 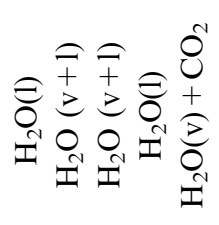 & 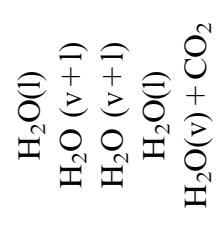 \\
\hline 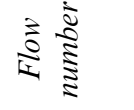 & $\stackrel{\sim}{\sim} \vec{\sim} \widetilde{\sim}$ & $\widetilde{\sim} \approx \stackrel{\sim}{\sim} \stackrel{\sim}{\sim}$ & 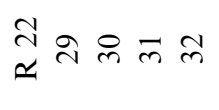 & $\vec{\alpha} m \dot{m} m$ \\
\hline$\stackrel{\Xi}{2}$ & $\stackrel{\text { กิ }}{\text { קิ }}$ & $\stackrel{\vec{\sim}}{\hat{\theta}}$ & $\begin{array}{l}\tilde{N} \\
\stackrel{\theta}{1}\end{array}$ & $\bar{\simeq}$ \\
\hline
\end{tabular}


Table 3 Plant properties

\begin{tabular}{|c|c|c|c|c|c|c|c|c|c|c|}
\hline 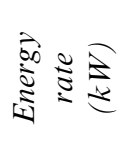 & 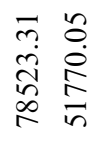 & 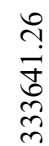 & 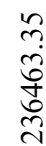 & 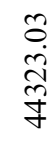 & $\begin{array}{l}\hat{\alpha} \\
\hat{\alpha}\end{array}$ & $\begin{array}{l}n \\
\text { ले } \\
\text { ले }\end{array}$ & $\begin{array}{l}\text { กิ } \\
\text { \&̊ } \\
\text { }\end{array}$ & 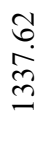 & $\begin{array}{l}\mathbb{J} \\
\infty \\
\stackrel{0}{0}\end{array}$ & $\begin{array}{l}\tilde{n} \\
\tilde{n} \\
\text { ปn }\end{array}$ \\
\hline 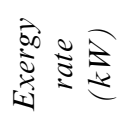 & 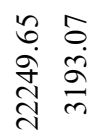 & $\frac{\stackrel{\infty}{+}}{\stackrel{5}{f}}$ & 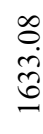 & $\begin{array}{l}F \\
\infty \\
\infty \\
\infty\end{array}$ & $\begin{array}{l}\hat{a} \\
\text { ஸे } \\
\text { o }\end{array}$ & $\stackrel{\text { f. }}{i}$ & $\begin{array}{l}2 \\
\dot{0} \\
\dot{8} \\
1\end{array}$ & $\begin{array}{l}0 \\
0 \\
0 \\
0\end{array}$ & 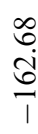 & $\stackrel{?}{i}$ \\
\hline 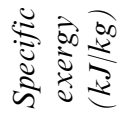 & 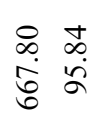 & $\stackrel{n}{\varrho}$ & $\begin{array}{l}+ \\
0 \\
0\end{array}$ & $\stackrel{n}{n}$ & & $\underset{+}{\stackrel{\Xi}{+}}$ & $\bar{\sigma}$ & $\stackrel{n}{i}$ & 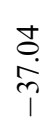 & $\stackrel{\overline{0}}{\ddot{2}}$ \\
\hline 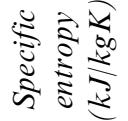 & 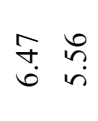 & กี & $\stackrel{\text { I }}{\circ}$ & ñ & in & in & î & $\stackrel{\overbrace{}}{i}$ & & oे \\
\hline 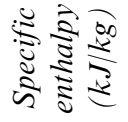 & $\begin{array}{ll}\infty & \infty \\
\infty & \infty \\
0 & \tilde{n} \\
\ddot{n} & n \\
& n\end{array}$ & $\begin{array}{l}\infty \\
0 \\
\dot{0} \\
\dot{I}\end{array}$ & $\begin{array}{l}\bar{b} \\
\end{array}$ & $\begin{array}{l}\infty \\
0 \\
\dot{0} \\
\pm \\
\end{array}$ & $\begin{array}{l}\stackrel{+}{+} \\
\stackrel{+}{+}\end{array}$ & $\frac{n}{n}$ & $\frac{\grave{N}}{\stackrel{N}{N}}$ & 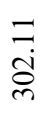 & 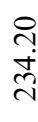 & $\begin{array}{l}m \\
\infty \\
\infty \\
\infty\end{array}$ \\
\hline 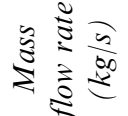 & $\begin{array}{l}\stackrel{N}{m} \\
m \\
m\end{array}$ & $\begin{array}{l}\tilde{\sigma} \\
\stackrel{+}{N} \\
\tilde{N}\end{array}$ & $\begin{array}{l}\text { \& } \\
\dot{J} \\
\text { g }\end{array}$ & $\frac{\infty}{\stackrel{1}{c}}$ & $\vec{n}$ & $\vec{m}$ & $\stackrel{?}{\stackrel{f}{+}}$ & $\stackrel{?}{\stackrel{\sim}{+}}$ & ले & शे \\
\hline $\begin{array}{l}\vdots \\
\vdots \\
\vdots \\
\vdots\end{array}$ & $\begin{array}{ll}\stackrel{0}{0} & 0 \\
0 & 0\end{array}$ & $\frac{0}{0}$ & $\stackrel{0}{\circ}$ & $\frac{0}{0}$ & $\stackrel{\infty}{8}$ & $\begin{array}{l}\bar{\sigma} \\
0 \\
0\end{array}$ & $\overrightarrow{0}$ & ஜ̂. & $\stackrel{8}{0}$ & $\stackrel{0}{0}$ \\
\hline $\begin{array}{ll}\text { కิ } \\
\text { ป }\end{array}$ & $\stackrel{\infty}{+} \stackrel{\Re}{+}$ & $m$ & จे & $m$ & $n$ & $\cong$ & ร & $\cong$ & in & 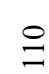 \\
\hline$\frac{\Xi}{5}$ & 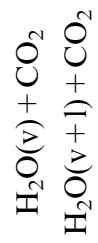 & 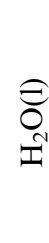 & $\begin{array}{l}0 \\
0 \\
\end{array}$ & 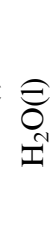 & 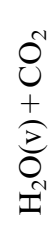 & \begin{tabular}{l}
0 \\
0 \\
+ \\
\multirow{2}{*}{} \\
0 \\
$I$ \\
$I$
\end{tabular} & ర & ర & ঠ & o \\
\hline$\frac{\bar{c}}{\bar{c}}$ & $\hat{n} \infty$ & ले & ঔ & 号 & F & $\stackrel{\mathcal{Y}}{\gamma}$ & $\stackrel{\Re}{\forall}$ & \& & & † \\
\hline $\begin{array}{l}\stackrel{\Xi}{\Xi} \\
\vdots \\
\vdots \\
\vdots \\
0\end{array}$ & : & $\begin{array}{l}\overline{0} \\
0 \\
0 \\
0 \\
0\end{array}$ & & & 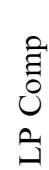 & & 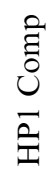 & & 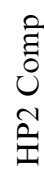 & \\
\hline
\end{tabular}




\section{Performance evaluation}

Exergy distribution based on the wellhead exergy using the data calculated in Tables 2 and 3, is shown in Figure 2. Nine production wells provide a total exergy of $53,586 \mathrm{~kW}$ at the wellhead. Overall exergy balance of the system is shown in Figure 3. The figure indicates that the net electricity generation accounts for only $27.2 \%$ of the total exergy input while the loss is $72.8 \%$. Of the $72.8 \%$ exergy loss, $58.5 \%$ is in the steam field, $14.3 \%$ in the plant.

Figure 2 Exergy flow chart of Kizildere Geothermal Power Plant

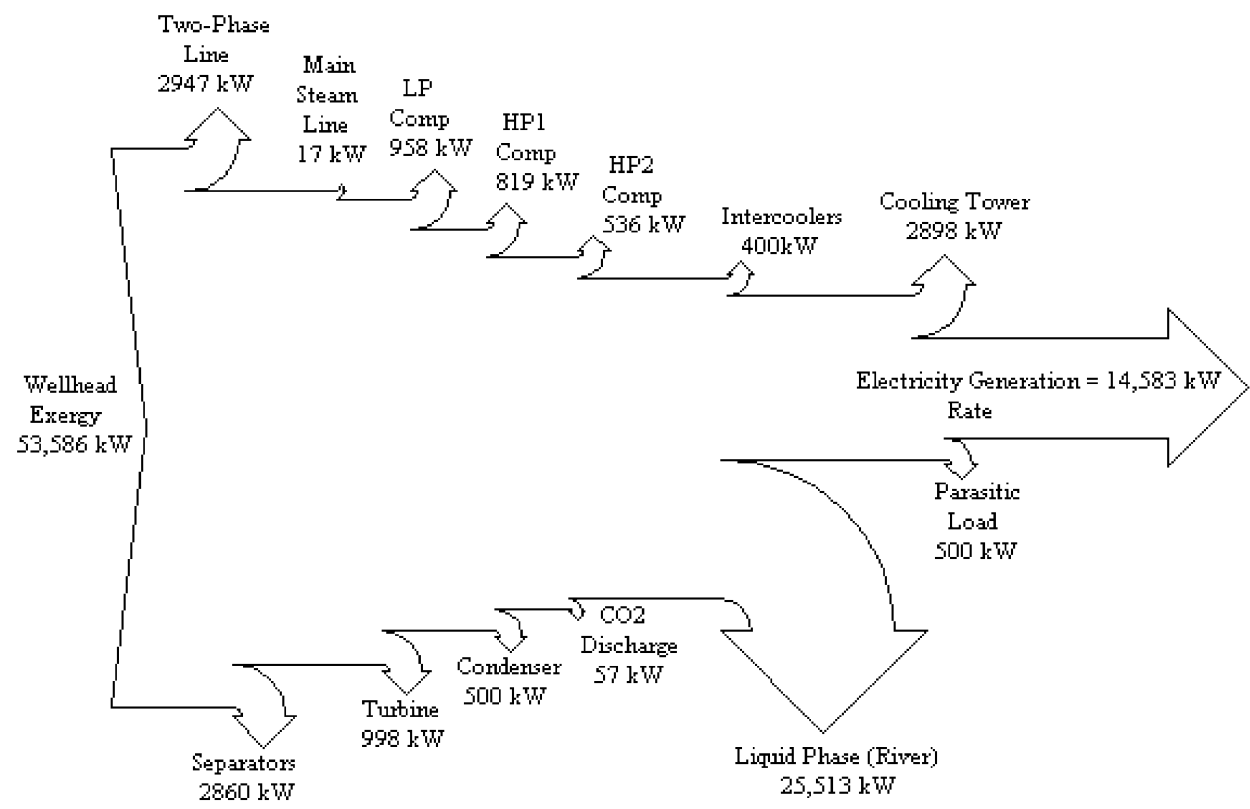

Figure 3 Overall exergy balance of the system

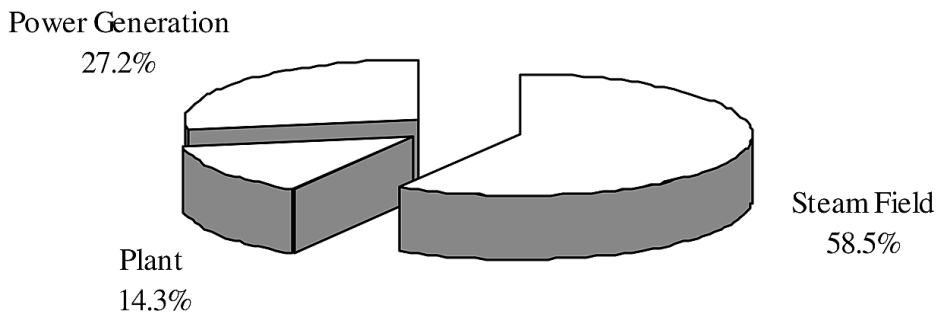

In Figure 4, steam field exergy losses are broken down into its components. A total exergy of $2947.20 \mathrm{~kW}$ is destroyed in the two-phase line, which corresponds to $9.4 \%$ of the total steam field losses. During the separation process, exergy destruction is accounted as $9.1 \%$. The liquid phase which leaves the separator and is sent to the river, constitutes $81.5 \%$ (or $25,513 \mathrm{~kW}$ ) of the steam field losses. 
Figure 4 Breakdown of the steam field exergy losses

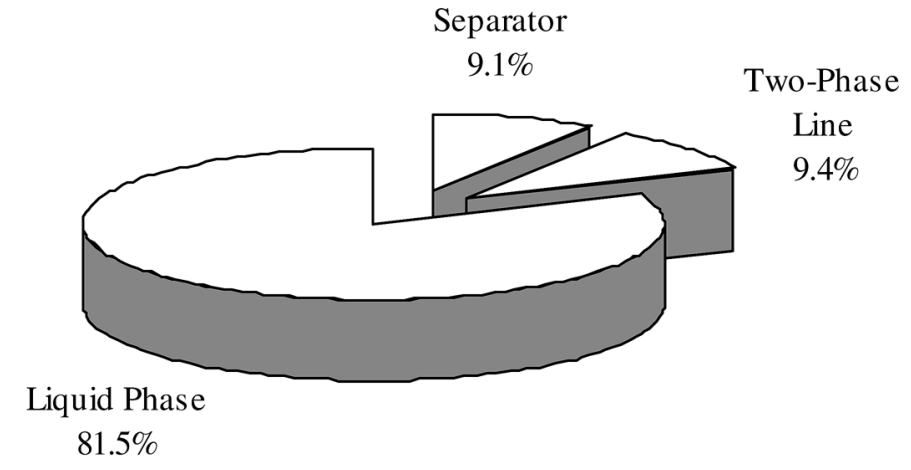

To be able to identify the contribution of exergy consumers in the plant, exergy losses are categorised into turbine, compressor unit, intercoolers, heat rejection system (condenser + cooling tower) and $\mathrm{CO}_{2}$ discharge and given in Figure 5. The steam is carried to the turbine-generator unit through the main steam line and during this transmission, $16.60 \mathrm{~kW}$ exergy is destroyed by friction, heat loss and condensation traps. During the expansion process in the turbine-generator unit, exergy loss is accounted as $998.10 \mathrm{~kW}$ (or $13.1 \%$ ). Following the turbine, steam flows to the condenser where the heat rejection process occurs. Exergy loss in the condenser is accounted as $500.40 \mathrm{~kW}$ which is $6.6 \%$ of the total plant exergy losses. NCGs, which move with the steam, are extracted from the condenser by compressors, which consist of three-stages with intercooling. Total exergy destruction in the compressor unit is $2312.90 \mathrm{~kW}$ which corresponds to $30.4 \%$. Total energy use of the compressors with $75 \%$ compressor efficiency is $1571.15 \mathrm{~kW}$ which is met by the turbine output. Besides compressors, the other parasitic losses such as fans, pumps, driers, demisters, etc., consume around $472 \mathrm{~kW}$ energy (Gunerhan, 2000) and the exergetic losses of these parasitic loads is assumed to be $500 \mathrm{~kW}$. Total parasitic loads account for $37.0 \%$ including compressors. Intercoolers consume $400 \mathrm{~kW}$ ( or $5.3 \%$ ) exergy because of the irreversible heat transfer process. $\mathrm{CO}_{2}$ leaves the last stage compressor and is sent to the $\mathrm{CO}_{2}$ plant with a $57.10 \mathrm{~kW}$ exergy potential which is $0.75 \%$. Condensate from the condenser is pumped to the cooling tower to be cooled down and reused in the condenser as cooling water. Exergetic losses in the cooling tower account for $2898.20 \mathrm{~kW}$, which is $38.1 \%$ of plant losses. The losses of the heat rejection system, which consists of condenser and cooling tower, total $44.7 \%$.

The overall performance of the power plant should be measured by comparing the net power delivered to the busbar with the exergy rate in the reservoir and that at the wellhead. The net second-law efficiency based on the reservoir exergy, is used to compare the plant performance to other geothermal power plants, particularly where they have the same cycle types. The net second-law efficiency based on the wellhead exergy, is used to compare the plant performance with other thermal/fossil-fuel power plants.

The overall second-law efficiency of Kizildere GPP is $27.2 \%$ based on wellhead exergy. The second-law efficiency of fossil-fuel power plants is $30-40 \%$ (Setiawan, 1996). Kizildere GPP exhibits a low performance compared with the FFPPs. 
Figure 5 Breakdown of the plant exergy losses

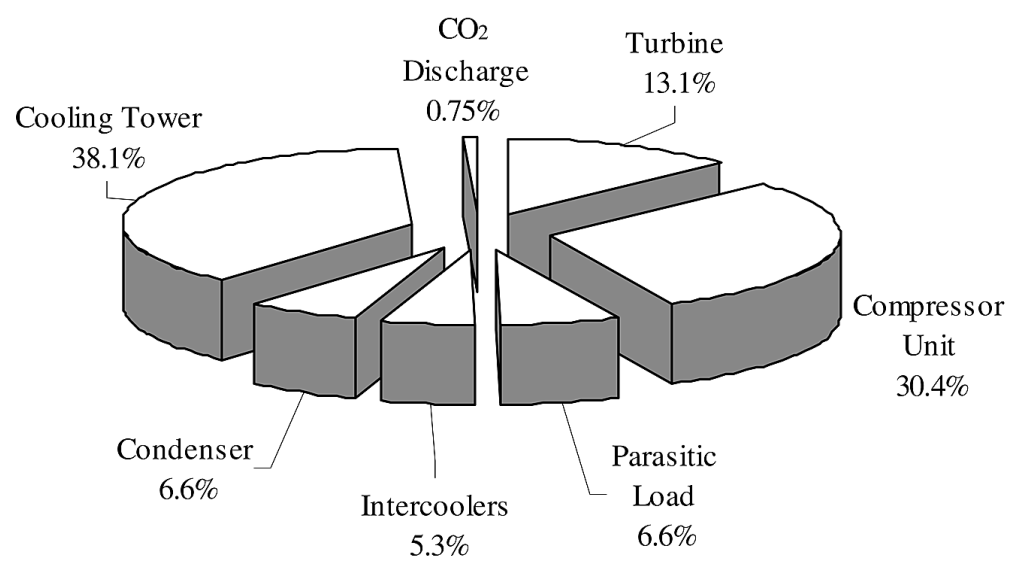

The overall second-law efficiency of Kizildere GPP is $24.3 \%$ based on reservoir exergy. Table 4 gives the comparison of overall second-law efficiencies of various GPPs based on reservoir exergy. Kizildere GPP exhibits an 8-27\% lower efficiency compared with the other single-flash geothermal power plants.

Table 4 Comparison of overall second-law efficiencies of various geothermal fields (Setiawan, 1996)

\begin{tabular}{llc}
\hline Type & Power plant & $\begin{array}{c}\text { Overall second-law efficiency based } \\
\text { on reservoir exergy }\left(\eta_{I I}\right)(\%)\end{array}$ \\
\hline Single flash & Salak (Unit 1 \& 2) -Indonesia & 30.4 \\
& Ahuachapan (Unit 1 \& 2)-El Salvador & 33.1 \\
& Kakkonda-Japan & 26.5 \\
& Otake-Japan & 29.0 \\
& Kizildere-Turkey & 24.3 \\
Single and & Ahuachapan (Unit 1.2 \& 3)-El Salvador & 38.2 \\
double flash & Cerro Prieto-Mexico & 33.2 \\
Dry steam & Darajat-Indonesia & 52.4 \\
& Kamojang (Unit 2 \& 3)-Indonesia & 48.4 \\
\hline
\end{tabular}

Exergy input-output, exergy loss and exergetic efficiencies of the major equipment in the plant is given in Table 5. The exergetic efficiency of turbine-generator unit is calculated as $92 \%$. The LP compressor has $93 \%$ efficiency while second and third stage HP compressors have 85 and $70 \%$ efficiencies, respectively. Decreasing efficiency indicates increasing NCG fraction in the compressor. The overall compressor unit efficiency is $55 \%$ which is quite low because of the high NCG content. Exergetic efficiencies of the condenser and cooling tower are 91 and $37 \%$, respectively. Irreversible heat transfer to the environment causes low efficiency in the cooling tower. 
Table 5 Exergy losses and exergetic efficiencies for the main plant components

\begin{tabular}{|c|c|c|}
\hline Principal scheme of exergy flow & $\begin{array}{l}\text { Exergy loss } \\
E_{L}(k W)\end{array}$ & $\begin{array}{c}\text { Exergetic efficiency } \\
\varepsilon(-)\end{array}$ \\
\hline TURBINE & 998.13 & 94.8 \\
\hline $\mathrm{E}_{\mathrm{E}}^{\mathrm{COMP}}$ & 958.27 & 93 \\
\hline EO & 818.97 & 85 \\
\hline$\underbrace{45}_{\text {COMP }} \mathrm{E}_{\text {in, comp }}^{\text {HP 2 }}$ & 535.65 & 69.6 \\
\hline $46 E_{\text {out,comp }}=57.12 \mathrm{~kW}$ & & \\
\hline
\end{tabular}


Table 5 Exergy losses and exergetic efficiencies for the main plant components (continued)

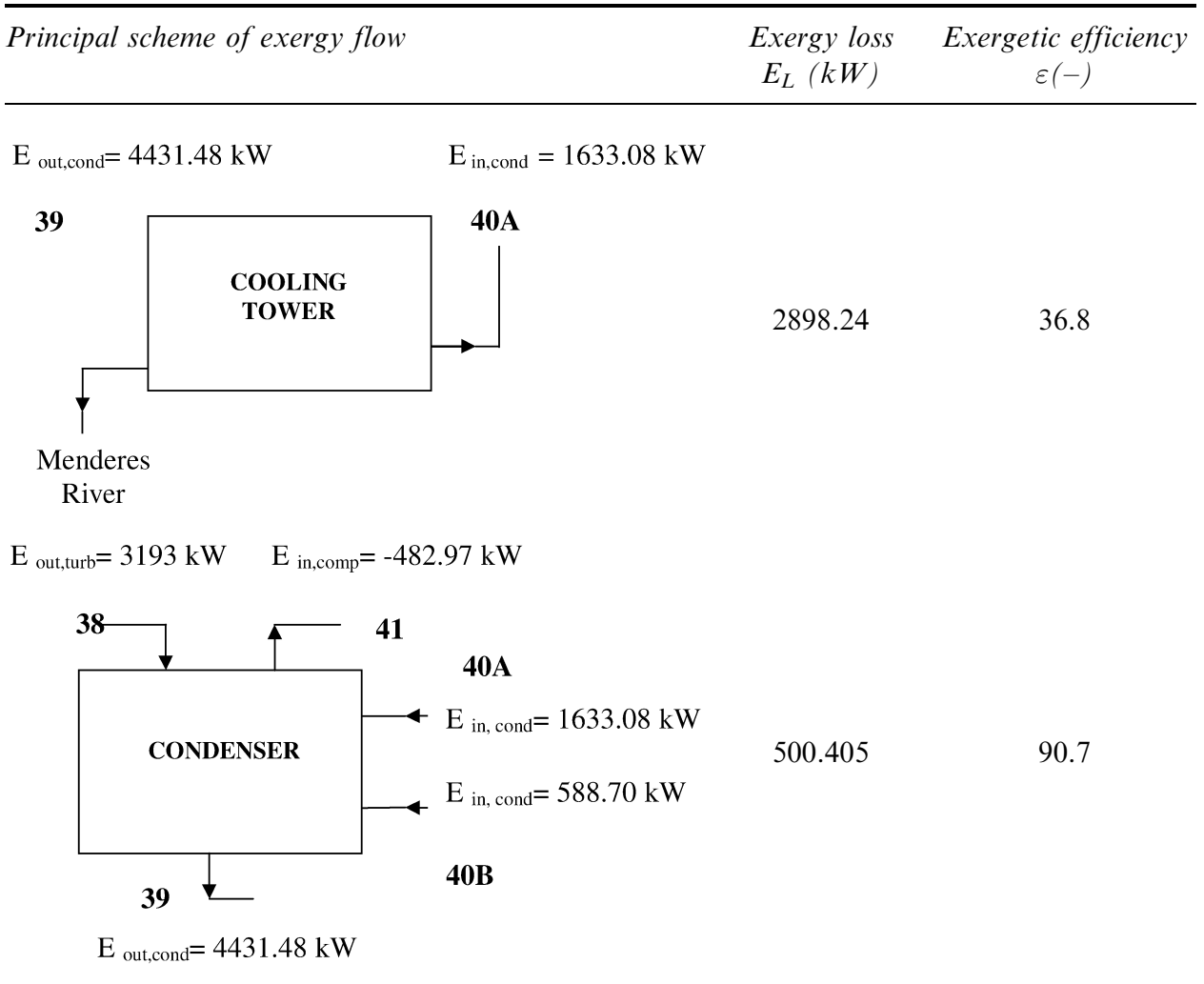

Besides exergy, energy values for each state are calculated and given in Tables 2 and 3. Production wells provide a total energy of $254,529 \mathrm{~kW}$ in the reservoir. There is no energy loss through the well because the process is assumed to be isenthalpic. The initial energy breakdown for steam field and plant indicates that the energy rate at which the liquid leaves the separator is $64 \%$ which is waste heat. The steam contains $31 \%$ of total energy input; $5 \%$ is lost in the separators and two-phase line. A further breakdown for plant exhibits that heat rejection system responsible for the largest energy loss, which is $65.9 \%$ of total plant losses. Net work output of the plant is only $18.6 \%$ of total steam input to the turbine. The compressor unit consumes $3.7 \%$ and the rest is spent for the turbine-generator unit, intercoolers and other parasitic losses.

\section{Conclusions}

In evaluating the performance of a non-cyclic GPP, exergy analysis has shown a better insight for the losses in electric power generation and the overall performance should be based on the second-law efficiency rather than first law. Energy analysis misleads the determining the inefficiencies in the system. 
In Kizildere GPP, no energy loss is encountered in the wells while exergy analysis demonstrates that the loss through the wells is $10 \%$ of the reservoir input. Similarly, energy loss in the compressor unit of the plant accounted for $3.7 \%$; however, the exergy loss due to irreversibilities and high NCG content accounts for $30.4 \%$.

Overall second-law efficiency based on wellhead and reservoir exergy is 27.2 and $24.3 \%$, respectively. The plant exhibits approximately $8-27 \%$ lower efficiency compared with the other single-flash GPPs and FFPPs because of extremely high NCG content and low steam fraction, which is only $10-20 \%$ of the total well fluid.

The overall breakdown in energy and exergy losses indicates that the largest destruction is accounted in the steam field as 69 and $58.5 \%$, respectively. Steam field energy losses are approximately $15 \%$ higher than the exergy losses while the rate is more significant for the plant. Energy and exergy losses in the plant are 25.3 and $14.3 \%$ respectively. The resulting electricity generation rate is $5.7 \%$ based on energy analysis and $27.2 \%$ based on exergy analysis.

The breakdown points out that efforts to increase overall efficiency should focus on the steam field. The exergy losses in the steam field can be further broken down into its components. The major exergy destruction with a share of $81.5 \%$ is the waste heat by liquid discharge to the river. A secondary-flash using an additional low pressure turbine or low temperature bottoming cycles, for instance the binary or Kalina cycle which uses heat from waste brine of the separators to vaporise a secondary working fluid, will increase the efficiency significantly. The thermal potential of waste fluid at the separator exit is $178.6 \mathrm{MWt}$. If it is assumed that only $5 \%$ of this can be converted into electricity, the additional electricity capacity of this waste fluid would be around $9 \mathrm{MW}_{\mathrm{e}}$, but each alternative should be evaluated on the technical and economical bases as well.

Besides unused heat potential, discharge into the river causes thermal and chemical pollution. The high boron content of the discharged fluid threatens agriculture. The boron concentration in the river, which is used for irrigation of a major plain in the region, exceeds the upper limit of $1 \mathrm{ppm}$ for irrigation in summertime. Injection, therefore becomes essential in the field for environmental protection and reservoir stability.

In the plant, the cooling tower is the major energy and exergy consumer accounting 65.9 and $38.1 \%$ of the total plant losses, respectively. Thus, it has the largest improvement potential. The second largest consumer in exergy distribution is the compressor unit with $30.4 \%$. Compared with a $3.7 \%$ energy loss, exergy loss is significant.

Based on exergy analysis, the equipment which should be considered for improvement in the plant is the cooling tower and the compressor unit. The exergetic efficiencies of the cooling tower and the overall compressor unit are low as a result of high exergy losses. Cooling tower design should be re-evaluated and the inefficient gas removal system should be replaced with a more efficient one.

GPPs contain a considerable amount of NCGs, thus the NCG content should not be omitted throughout the process and the dead state properties should reflect the specified state properties. 


\section{References}

Bilgen, E. and Takahashi, H. (2002) 'Exergy analysis and experimental study of the heat pump systems', Int. Journal of Exergy, Vol. 2, pp.259-265.

EGIC - Electricity Generation Incorporated Company (2002) 'Personal communication'.

Gokcen, G., Ozturk, H.K. and Hepbasli, A. (2004) 'Overview of Kizildere geothermal power plant in Turkey', Energy Conservation \& Management, Vol. 45, No. 1, pp.83-98.

Gunerhan, G.G. (2000) 'Theoretical and experimental investigations on condensation/boiling modelled heat exchangers (reboilers) designed for removal of non-condensable gases from geothermal steam', PhD Thesis, Ege University-İzmir-Turkey (in Turkish).

Hall, N.R. (1996) 'Gas extraction systems', in M.G. Dunstall (Ed.) Geothermal Utilisation Engineering Lecture Notes, 4.62-4.70, Geothermal Institute, The University of Auckland, New Zealand.

Khalifa, H.E. and Michaelides, E. (1978) 'The effect of noncondensable gases on the performance of geothermal steam power systems', US Department of Energy, Report No. CATMEC $/ 28$.

Michaelides, E.E. (1982) 'The influence of non-condensable gases on the network produced by geothermal steam power plants', Geothermics, Vol. 11, pp.163-289.

Montero, G. (1990) 'Evaluation of the net work of a turbine operated by a mixture of steam and non-condensable gases', Proc. of 12th New Zealand Geothermal Workshop, Vol. 11, pp.163-174.

Nikulshin, V., Wu, C. and Nikulshina, V. (2002) 'Exergy efficiency calculation of energy intensive systems', Int. Journal of Exergy, Vol. 2, pp.78-86.

Setiawan, B. (1996) 'Exergy analysis and performance evaluation of Salak geothermal power plant, Indonesia', Project Report, No: GEOTHERM 96.24, Geothermal Institute, The University of Auckland, New Zealand.

Song, T.W., Sohn, J.L., Kim, J.H., Kim, T.S. and Ro, S.T. (2002) 'Exergy-based performance analysis of the heavy-duty gas turbine in part-load operating conditions', Int. Journal of Exergy, Vol. 2, pp.105-112.

Struchtrup, H. and Rosen, M.A. (2002) 'How much work is lost in an irreversible turbine', Int. Journal of Exergy, Vol. 2, pp152-158.

TGA - Turkish Geothermal Association (2003) www.tga.org.tr

Vorum, M. and Fritzler, E.A. (2000) 'Comparative analysis of alternative means for removing non-condensable gases from flashed-steam geothermal power plants', $N R E L / S R-550-28329$.

WEC-TNC, World Energy Council-Turkish National Committee (2000) 1999 Turkey Energy Statistics.

\section{Nomenclature}

$\begin{array}{ll}\dot{E} & \text { Exergy value }(\mathrm{kW}) \\ \mathrm{f} & \text { Non-condensable gas fraction }(-) \\ \mathrm{h} & \text { Specific enthalpy }(\mathrm{kJ} / \mathrm{kg}) \\ \dot{m} & \text { Flow rate }(\mathrm{kg} / \mathrm{s}) \\ \mathrm{P} & \text { Pressure }(\mathrm{kPa}) \\ \mathrm{s} & \text { Specific entropy }(\mathrm{kJ} / \mathrm{kgK}) \\ \mathrm{T} & \text { Temperature }\left({ }^{\circ} \mathrm{C}\right) \\ \dot{W} & \text { Work }(\mathrm{kW})\end{array}$


Greek symbols

$\begin{array}{ll}\varepsilon & \text { Exergetic efficiency (-) } \\ \eta_{I I} & \text { Second-law efficiency (-) }\end{array}$

Subscripts

$0 \quad$ Dead state

$\mathrm{CO}_{2} \quad$ Carbon dioxide

cond Condenser

comp Compressor

ct Cooling tower

e Electrical

in Inlet

L Loss

mix Mixture

out Exit

t Thermal

turb Turbine 